\title{
HISTORICAL DOCUMENTATION OF EVENTS THROUGH VISUAL LANGUAGE: THE OCHIGBO'S PAINTINGS IN RETROSPECT
}

WOLE OLOIDI

(Received 21 January 2016; Revision Accepted 9 December 2016)

\begin{abstract}
The history of painting dates back to the cave painting period in Altamira in Northern Spain. Then, it was not seen as a source of documentation but rather, as a gateway to catching the painted animals as prey. Today, modern painters paint because of circumstances surrounding the rationale for such paintings. Ochigbo keyed into this perspective and he was never stingy with the reality of life in his paintings. The purpose of modern painting is such that communication should take place non-verbally, using visual language. Mostly, colours without paints were made in his works, with the same (if not more) functions, interpretations and references. In his paintings, plastics, rubber and other materials were used to intimate the art lovers with the rudiments of in- depth understanding of the use of alternative materials. The problem of preservation was addressed as he tried to use extraneous materials as binder. The thrust of this paper is to expose the society to the fact that artist can equally communicate through his art works, and not for painters to paint for aesthetic purposes only, but to educate, document, correct and inform the public.
\end{abstract}

KEYWORDS: Painting, Communication, Extraneous, Materials, Aesthetic, Visual language, Documentation.

\section{INTRODUCTION}

Born in Benue State, Best Ochigbo is a professor of painting at University of Uyo and a one-time Inspector of Education at the Ministry of Education, Benue State. He has produced numerous paintings and has equally been able to convince anyone that color could be achieved not only with oil paints, but through the creative exploration of local materials. $\mathrm{He}$ has experimented with the diverse painting materials like colored plastics, clay and kaolin. His painting is a philosophical, narrative and message carrier. Through his paintings, one would know that the style and techniques of his paintings have shown clearly that the interpretation of works of art is very important.This paper therefore centers on the documentation of events that occur in a dayto-day events, either as actions, activities or states of individual or collectivity. He has used his creativity to convey messages to both educated and non- initiate into the academic ministry.

Creativity in line with the history of painting is an elastic tendon starting from the very first pictures ever made, notably, by the cave painters of hunters and animals in AltamiraNorthern Spain. Although, the definition of what painting is, can be best defined by individual artist. This is because the way one painter sees a particular painting is different from that of the others. The purpose was initially not for documentation but, rather,as a means through which the painters could interpret and communicate to people through his paintings. Communication as defined by Farrant (1982) is the process of passing an understandable message from one person to another, in diverse ways, as long as the creativity could carry him. In essences, Ochigbo's paintings have created a

WoleOloidi, Department of Visual Arts and Technology, Faculty of Environmental Sciences, Cross River University of Technology, Calabar, Cross River State, Nigeria. 
unique stanza, quite different from the above rationale into using his paintings to document, educate, inform, communicate and express the situation in the society in a painterly platform.In the Nigeria context, the need to re-awaken people's mindset towards knowing the right thing to do is the basis of Ochigbo's paintings as he addresses the needs and aspirations of the society, and as he touches the social, political, religious and culture aspects of the society.

Each style grows out of the styles that came before it. Every great artist adds to the accomplishments of earlier painters and influences later painters. We can enjoy a painting for its beauty alone, its lines, forms, colors and composition (arrangement of parts) may appeal to our senses and linger in our memories. But enjoyment of art increases as we learn when, why and how it was created. A painting always describes something. This is why Ochigbo's paintings align with the principles laid down by National Policy on Education, According to a section in this policy (2004), 'teacher education provides teacher with the intellectual and professional background adequate for their assignment,and make them adaptable to changing situations' It may describe the artist's impression of a scene or person by describing the artist's feelings about the art of painting itself. Suppose, for example, the artist paints a picture of the bright of Venus, the Roman goddess of love-a subject that has been used many times. The viewer may not learn anything new about the subject from the more recent version that could not have been learned from the older one. Why, then, do painters bother to depict the same scene again? The answer is that they want to tell us something new about the way the scene can be painted. In a way, the artist is saying, "I have painted the birth of Venus as no other artist before me has painted it". The artist not only depicts the birth of Venus but also makes a statement about the art of painting itself. Many factors have influenced the history of painting. Geography, religion, national characteristics, historic events, and the development of new materials, all help to shape the artist's vision. Throughout history, painting has mirrored the changing world and our ideas about it. In turn, artists have provided some of the best records of the development of civilization, sometimes revealing more than the written word.

The art of using paint in a picture, as a protecting coat or as decoration is called painting. It can also be seen as the art of practice of applying paint, pigment, color or other medium to a surface (support base). The medium is commonly applied to the base with a brush but other implements such as knives, sponges and airbrushes can be sued. Painting may have for their support, such surfaces as walls, paper, canvas, wood, glass, lacquer. Others are: leaf, copper or concrete which in essence may incorporate multiple other materials, including sand, clay, paper, gold-leaf as well as other found objects. In art, the word painting explains both art and the result of the action. However, the term painting is also used outside of art as a common trade among craftsmen and builders. Painting is a mode of expression, and the forms are numerous, Examples could be drawn from drawing, composition or abstraction among these, numerous aesthetics may serve to manifest the expressive and conceptual intention of the practitioners.

\section{Ochigbo; Colors without Paints}

Localizing the art of painting could be seen in the early days of our early body decorators. Our parents found joy traditionally in painting their bodies as aesthetics were seen by them culturally as a binding principle to meet the aspiration of the society. As time went on, people began to see painting not only as an enduring profession as well as a means of documenting historical events but also to solve the problem of interpreting the societal activities. Historically, painting has to do with aesthetics which occurs in different body decorations ascolor depicts various actions, activities and states. It symbolizes locations and cultural areas, situations, conditions and traditions; it can also be used to convey a sense of awe or respect. Ochigbo in his quest for alternatives to get him more on board in painting, has creatively explored other materials like colored plastics, fibres, wood and sand, to mention a few. Color interpretation through the use of these creative materials play a major role in the execution of a particular works of art which in essence, has always made his works outstanding. A lot of philosophical meanings are attached to the used of art forms. Painting therefore has the African concept of religious beliefs; food, shelter, clothing are expressed through the art of painting. Any painting that does not reflect these forms cannot be rated as being representational in the social, political, religious and cultural aspects. 


\section{Analysis and Interpretation of Ochigbo's Paintings}

The paintings of Best Ochigbo notwithstanding, his creativity has been proved beyond reasonable doubt that,awareness has been created that art is an embodiment of creation. African art has gone beyond the shores of the west where paintings are mostly for aesthetics. African art strongly depicts art for life. In analyzing the works of the artist, two major things are involved: 'the subject matter' and 'content' in art. While subject matter explains the work of art-what it represents, content simply signifies the interpretation and meaning of the art work. All these are made possible because of the involvement of color, forms and structure to create a visual communicationtool for a work of art asexplained below:

\section{a. EFCC Cell. Best Ochigbo}

This painting depicts the consequences of corruption, embezzlement, fraud and other antisocial behaviors. The artist tries to show even from the choice of color-subdued, sober and repentant colors. The cell as depicted by the artist shows discomfort, loss of freedom of movement and above all there is a denial of what seems dear to you, through the use of lines as demarcations between one cell and the other. The painter shows clearly that there is nothing as good as living right of which the consequences always attract stiff penalty. With this message through Ochigbo's painting a lot has been passed across through the canvas. Painting of this sort localizes the message that is globally written on the pages of newspapers. It is worthy of note that this painting speaks across language barriers.

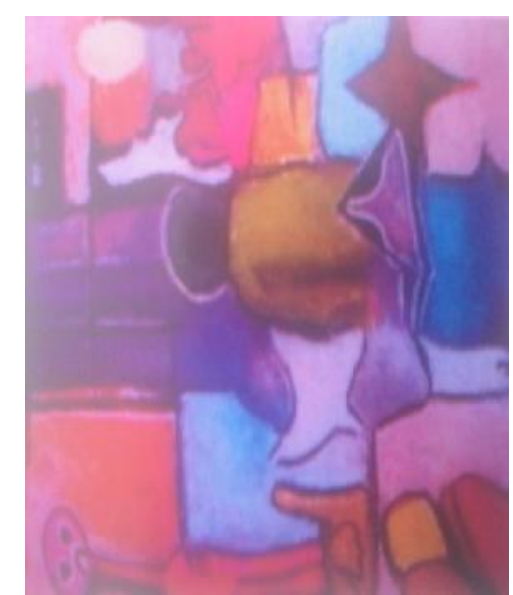

Figure 1:EFCC Cell. Best Ochigbo (2006)

\section{b. Whisper on the Po}

This painting reminds me of the youthful days when proper attention was paid to hygiene. The painter reminds one of the act and result of good parenthood. 'Whisper on the Po' is a painting of two kids emptying their bowels in a Po. The significance of this painting is both philosophical and psychological. The color is interpretatively subtle and at the same time, shows a good sense of intimacy. On the philosophical aspect, it shows the innocence of children as exhibited by the painting, even though there are millions of children out there who are used to modern toilet system. According to the painter, time is inexhaustible and can therefore generate a more comfortable arena for the upcoming children. The painter has also drawn the attention of Federal, State and Local governments on the need to create a comfortable working environment, where a good standard of living would not be compromised. 


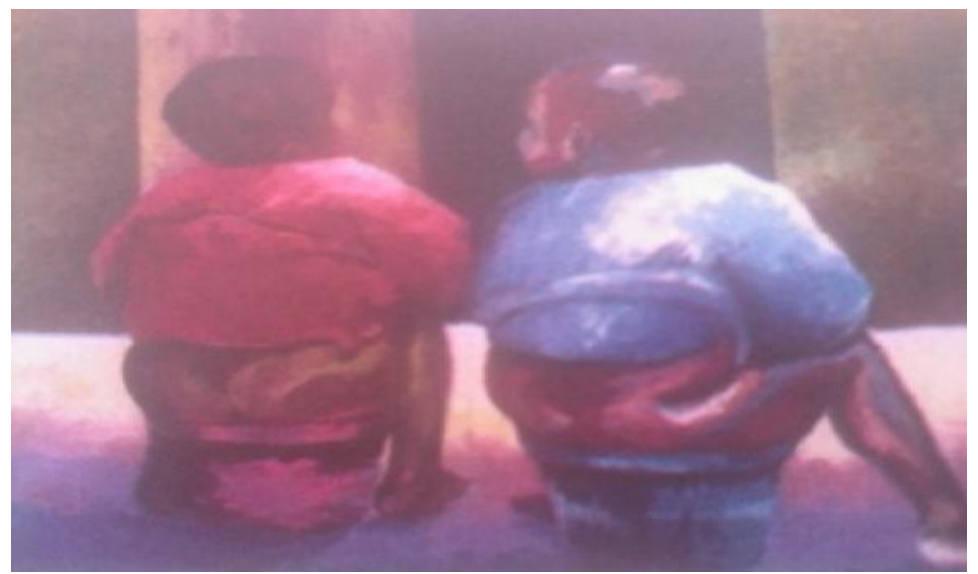

Figure 2: 'Friendly Whisper on the Po' Best Ochigbo( 2010)

\section{c. Revolutionary Sunset}

Culturally and traditionally, sunset is a symbol of withdrawal from work to rest. This painting simply speaks to man that after hard work, rest is uncompromisingly necessary. The sun is very hot from about 1200 p.m-300.p.m.
From 400.p.m -600.P.m, the sun is setting, an indication that whatever one is doing, there is need to lay that aside and create the span for rest. This painting says once nature can give itself rest, none has anoption than to follow the dictates nature.

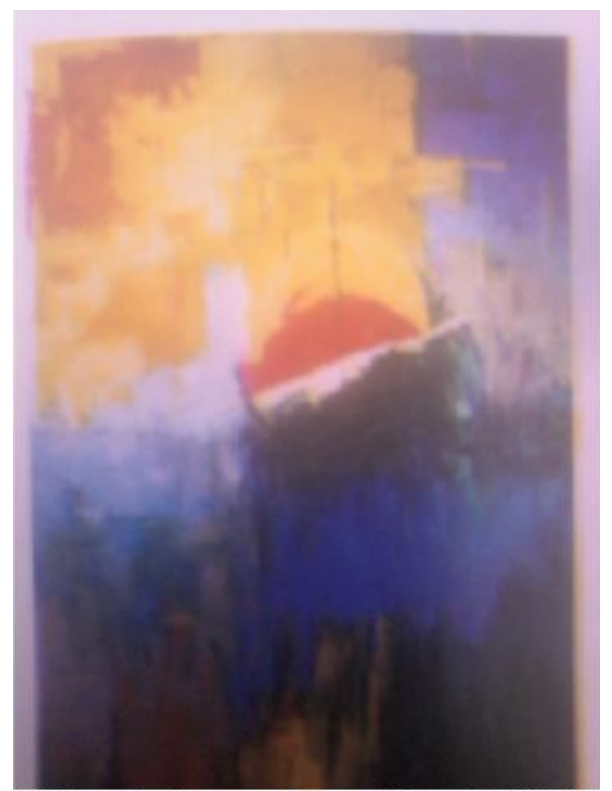

Figure 3:'Revolutionary Sunset’Best Ochigbo (2010)

\section{d. 'Hawker':}

Directly, the hawker signifies mobile shop which is rife in our society. Because of bad economic situation, many people cannot afford to own a shop; they prefer alternate hawking as a means of marketing their goods. This painting is a significant revelation of typical African woman who stands by, contributing her quota to the 
development and upkeep of the family. A painter needs to take some things into consideration why trying to communicate, one of which is that individual interpretation on a particular work of art ought to send signaled message to viewerswhich in essence should be informative.

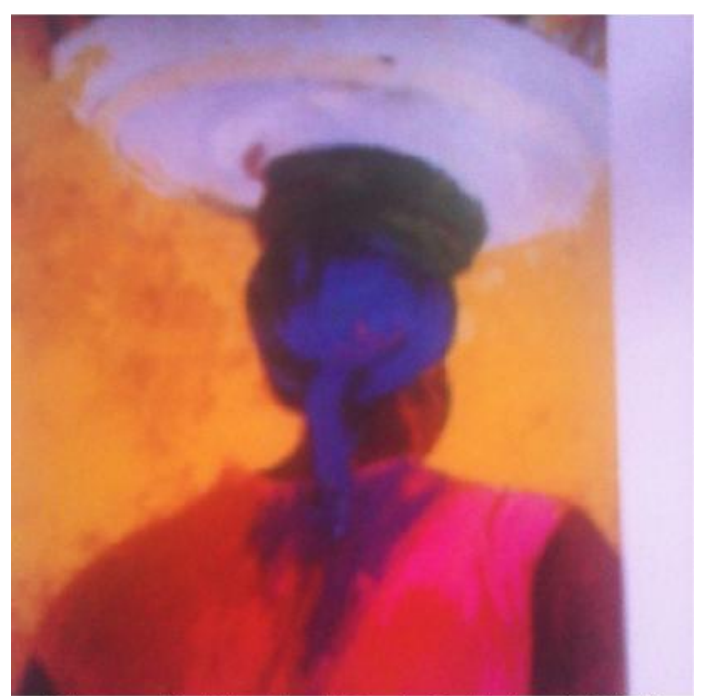

Figure 4: ‘Hawker' Best Ochigbo (2011)

\section{e. 'Breast feeding'}

A fascinating painting - a philosophical painting, using burnt plastic as a medium. The artist has documented the importance of breast feeding, as against the baby food from cans and plastics. This painting is a campaign against a neglect by most women who rather than allowing their child to enjoy the natural milk from where the child could grow mentally and naturally opt for artificial milk. The campaign in support of breast feeding is very self-explanatory in this
painting.Selecting Ochigbo's works for analysis and interpretation is in line with what was explained by Matthews and Platt (2003) that'the Western cultural heritage is vast, and any selection of works for a survey text reflects choices made by the authors'. Ochigbo' works were picked for analysis because of two major reasons; the works according to Matthews, 'blazed a new trail' through his choice of materials and two, his style is unique and exploratory. This is evident in 'the hawker' 


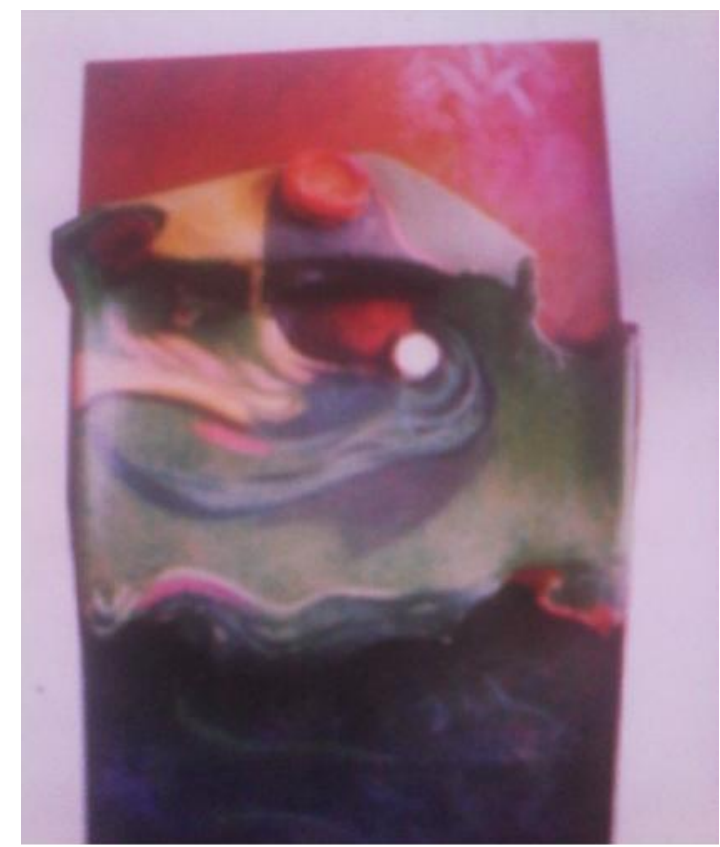

Figure 5:'Breast feeding' Best Ochigbo (2006)

\section{f. 'What is in it'?}

Dangerously depicted! It is an art of carelessness to allow a child of this nature have access to the kitchen, the painting explains this clearly as it sends signal to parents to be very watchful of their children not to get to dangerous areas within and around the house. Ochigbo scares a concerned parent by this painting expression. It is self-explanatory. Although this painting may be self-explanatory, there is need for art appreciators to still have their own judgment.Eichhorn et al (2008) say that using a five- step analysis can be used to explain or describe a painting. By this simple analysis, the artist has offered his own description leaving the viewers to make theirs. The inquisitiveness of the child is evident by his wisdom to increase his height through a support he climbed, what a wonderful world of risks and adventure!

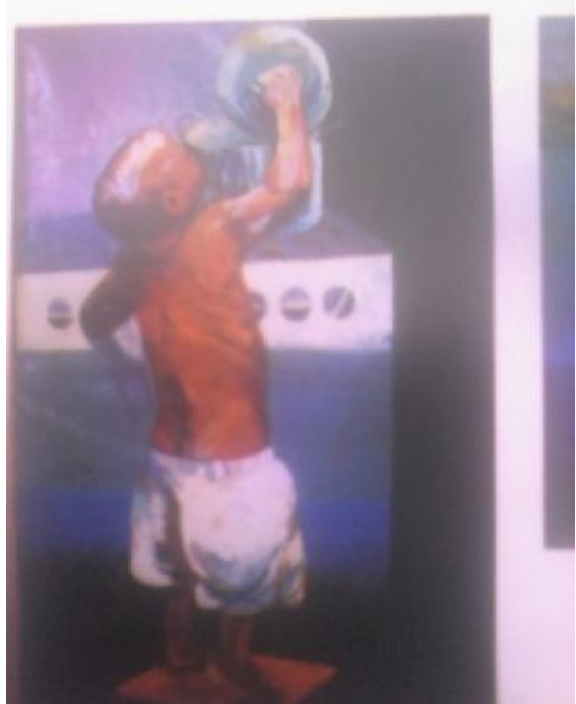

Figure 6:'What is in it'? Best Ochogbo (2006) 


\section{g. 'River Side'}

Going by the native trends of the society an African woman is very much at home with her daily routine. One of which is the traditional wayof water and its constituents. Ochigbo states in his painting that before the pipe borne water, Nigerians have been performing our streams and getting things done. With our natural streams, water is not a problem, as according to FelaAfro beat Musician...,"water no get enemy".

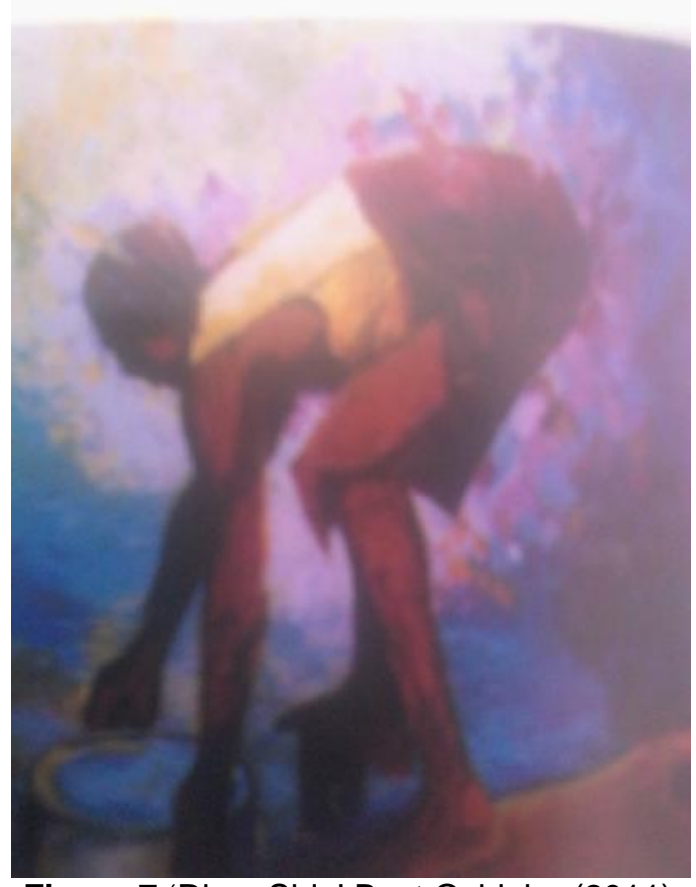

Figure 7:'River Side' Best Ochigbo (2011)

\section{h. 'Sacred Head'}

Traditionally and culturally, the typical Gwari woman considers her head as "sacred". Their shoulders, therefore, become the head where loads are placed. Thus painting has recorded the cultural event for the generations unborn. With this, it is recorded that those, who have not known the culture of Gwari people, shall by this painting know that the Gwari woman's head is sacred. This painting clearly supports what Jonaro and Altshuler (2006) say. As recorded, there may be as many styles of art as there are artists...no two thumbprints are exactly alike.By this, Ochigbo has created varieties of likeness through his paintings. 


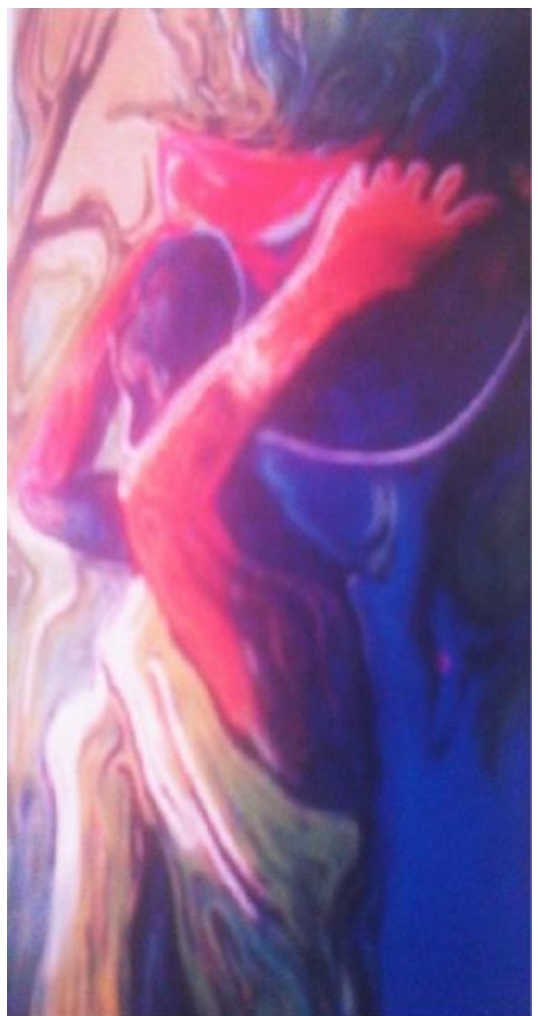

Figure 8:'Sacred Head' Best Ochigbo (2010)

All Ochigbo's paintings have the corrective, educative, inspirational encouraging and motivational trends. This is why this work remains classic and fresh in the minds of not only artists but the society at large. One thing is so unique about Ochigbo's painting, has in it the corrective, educative, inspirational, encouraging and motivational trends. This is why his works remain classic and fresh in the minds or not only artists but the society at large. One thing is so unique about Ochigbo's painting, he does not allow himself to be hindered by the limited materials rather he explores materials from his immediate environment.

Ochigbo's actions has taught many upcoming painters to look or rather (learn to look) beyond the shores of already made (imported) painting materials. Rather, his emphasis on the use of locally- sourced materials have made most painters to be explorative and adventurous. Most times, what cannot be expressed through writing or orally, can be expressed in a visual form. The implication of this method is that the titles of Ochigbo's paintings are mostly philosophical, therefore,creating an elastic food for thought, forcing the society to reason or figure out what the painting is trying to express.

\section{Submission}

The Ochigbo's paintings, in retrospect, can now be viewed as a submission of facts and attestation to the existence of Nigeria natural culture. Most people, particularly the illiterates can vividly interpret the paintings of Ochigbo and get the message in relations to particular situation. He may not have been the first to document events on canvas, the different is the fact that his paintings are corrective, educative and instructional through social, political, economic, and religious spheres.

Best Ochigbo has been able to prove beyond reasonable doubt that, art is science and that science is art. This statement has been proven through his application of materials. $\mathrm{He}$ is also a good manager in his professional right.Anderson (1989) says in every practice, it is the practitioner rather than the scholar who develops the discipline, who finds and tests new knowledge, and who teaches and sets good examples. 


\section{REFERENCES}

Anderson, L., 1989.The Effective Teacher.New York: McGraw Hill.

Chukuegwu, C., 2010. The Aina Onabolu Pioneering Influence."Modern Artistic Tendency in Nigeria; Its Influence on the Creative Development". Anthropologist 12(3)

Erchhorn E. A., 2008. Writing as a Cultural Act. Ontario: Thomson and Nelson.

Farrant, J., 1982. Principles and Practice of Education. China: Shrek Wah Tong.

Ikpakrunyi, Simon., 2010. "Emergence and Development of Modern Art" in Modern Nigeria Art, ARTEXPO NEW YORK 2010, ABUJA.National Gallery of Art. Retrieved 2011-05-22.

Janaro, $R$ and Altshiler., 2006.The Art of Being Human. New York: Pearson Longman.

Matthews, R and Platt, D., 2003. The Western Humanities. London:McGraw Hill.
National Policy on Education., 2004. Abuja, Federal Ministry of Education.

Ochigbo, B., 2006. A Lexicon of Art Terminologies Lagos: Minder International Ltd.

Ochigbo, B., 2011. A Hand book of Painting. Lagos: Roberti Minder International Ltd.

Ochigbo, B., 2015. Unveiling the meaningfulness in the meaningless creativity in Paintings Visual Vocabulary and Retrospective Exhibition. A $46^{\text {th }}$ Inaugural Lecture. University of Uyo: Uyo.

Oguibe, O., 2004. The Culture Game.New York: University of Minnesota Press.

Okpewho, I. F., 1999. The African Diaspora: African Origins and New World Identities, Indiana: University Press.

Oloidi, O., 2008.AinaOnabolu and the Development of Modern Nigerian Art. Lecture Notes on Aina Onabolu. Fine and Applied Arts, University of Nigeria Nsukka. 